\title{
Reorientasi Strategi Pembangunan Ekonomi yang Berorientasi pada Rakyat
}

\author{
Edy Suandi Hamid
}

The discourse on people' economy in crisis and in the strong wave of reform movement is undoubtedly relevant. This is because of impact of the crisis on the people economy which is extremely huge. This article describes what so called the "people economy" and how the system vis a vis the market system of economy. Further, this article also discusses how the economic gap happens in Indonesia and recommends a system which is feasible to cope with it.

\section{Pengantar}

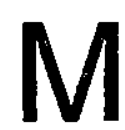
encermati data makro ekonomi yang terjadi dalam dua tahun terakhir ini, maka gambaran suram memang sangat nyata menggantung pada Perekonomian Indonesia. Oleh karena itu tidak mengherankan kalau suatu publikasi yang bertajuk "Laporan Konferensi tentang Krisis Ekonomi di Indonesia ", suatu laporan dari konferensi ekonomi yang diadakan Australian National University (ANU) Canberra dengan Fakultas Ekonomi Universitas Indonesia (1988) menyuratkan "Krisis ekonomi Indonesia yang berlangsung sejak pertengahan Agustus 1997 adalah merupakan krisis yang terparah di kawasan Asia dewasa ini maupun dalam sejarah peradaban manusia modern" (FE UI, 1999, h. 1). Walaupun kesimpulan itu masih bisa diperdebatkan, namun data kontraksi ekonomi tahun 1998 yang mencapai hampir $14 \%$, inflasi $77,63 \%$, kemerosotan nilai rupiah sekitar $80 \%$, meningkatnya angka kemiskinan secara drastis, yang menurut ILO mencapai 100 juta, serta bertambah besarnya angka pengangguran, bisa menjadi indikasi keparahan krisis ekonomi dewasa ini.

Dalam kondisi yang demikian, krisis pun meluas ke bidang-bidang lain, sehingga menjadi krisis yang multi dimensi, yang mencakup krisis ekonomi, politik, hukum, keamanan maupun krisis sosial. Bersamaan dengan ini melahirkan pula berbagai gerakan-gerakan dalam masyarakat yang merasa tidak puas dengan kondisi sekarang dan berbagai kebijakan yang ditempuh selama ini. Dalam konteks ekonomi, tuntutan yang semakin deras adalah keinginan untuk memberdayakan ekonomi rakyat banyak, yang selama ini dirasakan jauh tertinggal dibanding kekuatan ekonomi segelintir masyarakat Indonesia yang berada pada lapisan atas elite ekonomi nasional.

Membicarakan masalah ekonomi rakyat pada masa krisis dan di tengah-tengah tuntutan kuat akan suatu reformasi ekono- 
mi, memang terasa sangat relevan. Walaupun mungkin masih bisa diperdebatkan, saya termasuk yang berpendapat bahwa dampak krisis ekonomi yang berkepanjangan ini, secara absolut dan individual lebih parah menimpa kehidupan ekonomi rakyat, yakni sektor-sektor atau lapangan ekonomi yang paling banyak menampung angkatan kerja kita, atau sektor yang banyak menjadi tumpuan hidup sebagian besar rakyat. Memang dilihat secara relatif atau proporsional, berbagai prediksi yang ada menunjukkan kemerosotan angkanya sektor yang terkait dengan rakyat banyak masih lebih kecil dibanding sektor modern. Misalnya dalam kaitan prediksi pertumbuhan tahun 1998, BPS mengestimasi sektor pertanian masih tumbuh $0,26 \%$, sedang non-pertanian - 15,3 $8 \%$; golongan usaha kecil pertumbuhannya - 11, $21 \%$, usaha menengah besar - 14,19\%. Namun perlu dingat, bagi sektor ekonomi rakyat tersebut penurunan pertumbuhan tersebut terjadi di tengah pendapatan yang sudah sangat minim, sehingga langsung berpengaruh pada pemenuhan kebutuhan dasarnya. Oleh karena itu menjadi sangat penting untuk mengkaji aspek-aspek yang berkaitan dengan ekonomi rakyat tersebut, tidak saja dalam perspektif jangka pendek, melainkan juga untuk kepentingan jangka panjang, sebagai bagian untuk membangun sistem ekonomi Indonesia yang kokoh dan berorientasi pada kesejahteraan rakyat. Namun demikian, sesuai dengan tema seminar ini, perlu dikemukakan beberapa konsep yang berkaitan dengan ekonomi rakyat ini.

Sebagai suatu istilah, ekonomi rakyat atau ekonomi kerakyatan, masih sering menimbulkan pertanyaan. Apa itu ekonomi rakyat? Mengapa ada istilah ekonomi rakyat ataupun ekonomi kerakyatan? Apakah pelaku-pelaku ekonomi sekarang ini bukan rakyat? Apakah konglomerat itu bukan rakyat?". Pertanyaan semacam itu bukan hanya sekali muncul dalam forum-forum diskusi, seminar dan sejenisnya. Bahkan dalam pembicaraan sehari-hari pun nada pertanyaan demikian acap terlontar manakala mendengar istilah "ekonomi kerakyatan".

Memang kalau kita melihat dari segi semantiknya, mungkin menjadi aneh membuat suatu istilah "ekonomi kerakyatan". Karena kalau ada ekonomi kerakyatan ataupun ekonomi rakyat, berarti ada pula ekonomi lainnya, atau ekonomi non-rakyat. Ini kalau semata-mata melihatnya dari sisi bahasa. Namun istilah tersebut sebenarnya tidak bisa dilihat dari segi harfiahnya atau bahasa an sich. Hal tersebut perlu dilihat dari makna yar.g terkandung di balik istilah itu, dan untuk memahami maknanya perlu dilihat pula proses munculnya istilah yang belakangan ini menjadi sangat populer dan sering muncul di media massa kita.

\section{Konsep dan Munculnya Ekonomi Rakyat}

Istilah ekonomi kerakyatan bukanlah istilah baru. Istilah ini sudah muncul pada masa kolonial, yang dikemukakan Bung Hatta dalam konteks pemberdayaan ekonomi bangsa Indonesia yang waktu itu menjadi bangsa terjajah, miskin dan menjadi warga kelas tigà di negerinya sendiri. Istilah yang sama muncul lagi dalam gema yang cukup deras beberapa waktu terakhir ini. Ini menjadi obyek yang kian menarik perhatian masyarakat, khususnya kalangan pengamat ekonomi-sosial setelah dalam beberapa forum akademik dan forum resmi serta dialog dengan pers, dikemukakan oleh Dr. Ginandjar Kartasasmita di sekitar tahun 1994/1995, dan kini masuk juga -setelah diperdebatkan cukup lama -- dalam GBHN 1998, dan kemudian menjadi terminologi umurn yang seakan dilawankan 
Topik: Reorientasi Strategi Pembangunan Ekonomi ......., Edy Suandi Hamid

dengan ekonomi konglomerat.

Munculinya istilah ekonomi kerakyatan yang gencar saat ini sebenarnya merupakan pencerminan dari ketidakpuasan atas beberapa kenyataan yang ada dalam perekonomian kita. Perekonomian kita yang hingga tahun 1996 kian maju, dan tumbuh dengan pesat dan di atas rata-rata laju perekonomian dunia. Sektor industri menengah dan industri berat yang menggunakan teknologi canggih, sudah muncul. Rakyat Indonesia ada pula yang masuk dalam jajaran orang terkaya di kawasan Asia Tenggara serta Asia. Namun yang berkembang sangat pesat itu ternyata didukung dan dinikmati oleh segelintir rakyat Indonesia gencar belakangan ini lebih banyak dinikmati usaha skala besar. Dengan menggunakan data 1985-1992 ia menunjukkan bahwa sebanyak $28,68 \%$ perusahaan besar yang mengalami gradasi atau menjadi semakin besar, sementara perusahaan kecil hanya $9,31 \%$ dan perusahaan skala menengah $12,3 \%$.

Perkembangan yang dilihat awam secara kasat mata telah menimbulkan kecemburuan dan keprihatinan yang agaknya mendorong munculnya isyu-isyu ataupun pemikiran yang berdimensi pada skala usaha kecil atau yang berkaitan dengan ekonomi rakyat banyak. Jadi, dapat dikatakan muncul dan santernya istilah "ekonomi kerakyatan" tersebut sebagai refleksi dari biasnya pertumbuhan ekonomi yang didukung dan dinikmati oleh segelintir usaha besar ataupun para konglomerat yang sebagian bertindak sebagai monopolis dan oligopolis pada pasar komoditi tertentu. Perekonomian yang berkembang tersebut dipandang "lepas" dari akar kerakyatannya. Oleh karena itu diharapkan muncul suatu kebijakan yang lebih populis dan berorientasi pada masyarakat luas tersebut.

Akibat keadaan demikian munculah dikotomi ekonomi kerakyatan dan "ekonomi yang lainnya" tersebut. Memang kalau dilihat dari pelaku-pelaku ekonomi yang ada, entah itu yang berskala kecil, menengah, besar ataupun konglomerat, semuanya adalah "rakyat Indonesia". Artinya aktivitas produksi, konsumsi dan distribusi itu juga dilakukan oleh rakyat. Namun nafas dari ekonomi kerkayatan belakangan ini tidaklah demikian. Kesan yang kuat adalah adanya keinginan agar dalam pembangunan ekonomi ini keterlibatan rakyat banyak adalah besar. Artinya aktivitas-aktivitas tersebut dilakukan dan melibatkan sebagian besar rakyat. Dengan dasar itu, maka dapat dikatakan bahwa makna "ekonomi kerakyatan" tersebut adalah suatu perekonomian yang orientasinya pada keterlibatan rakyat banyak dalam aktivitas ekonomi atau aktivitas produksi, aktivitas konsumsi dan aktivitas distribusi (Edy Suandi Hamid, 1995). Ginandjar Kartasasmita, dalam pidato penerimaan gelar Doctor Honoris Causa dari UGM (April 1995) menyiratkan bähwa yang dimaksud ekonomi rakyat adalah: "ekonomi sebagian besar rakyat indonesia". Sedangkan Mubyarto (1997) mendefinisikan ekonomi rakyat sebagai kegiatan ekonomi yang dilakukan oleh rakyat yang dengan secara swadaya mengelola sumberdaya lokal apa saja yang dapat dikuasainya, dan ditujukan untuk memenuhi kebutuhan dasarnya dan keluarganya. Menurut Mubyarto, kekuatan dan daya tahan ekonomi rakyat tersebut terletak pada kemampuannya untuk berswadaya tersebut, yakni mengandalkan modal sendiri. Sedang Sarbini $(1988$, h. 27) mendefinisikan sebagai suatu perekonomian yang lebih menekankan pada pembagian kesempatan, yang berarti membagi rata pengikutsertaan seluruh masyarakat pada kegiatan ekono$\mathrm{mi}$, sosial dan politik.

Dengan pengertian di atas maka arah aktivitas ekonomi yang diharapkan adalah aktivitas-aktivitas di semua sektor ekono- 
mi, seperti sektor industri, pertanian, pertambangan, jasa-jasa, dan sebagainya, dengan melibatkan rakyat banyak untuk melakukannya. Ada kebebasan masyarakat untuk ikut bekerja atau menjadi pengusaha pada sektor-sektor itu, atau di lapanganlapangan usaha yang ada. Tak ada sektor produksi yang diperuntukkan bagi satu atau segelintir pengusaha. Mereka yang terlibat dalam akativitas itu berhak pula untuk memperoleh penghasilan ataupun upah yang layak untuk membiayai konsumsinya. Artinya, berbagai penghasilan atau keuntungan dari segala penerimaan dari aktivitas ekonomi itu bisa dinikmati oleh sebagian besar rakyat yang terlibat dalam produksi itu. Termasuk dalam pengertian ini adalah adanya suatu distribusi yang adil sebagai akibat dari adanya aktivitas produksi di atas. Jadi, perkembangan produksi atau output nasional yang tersusun meningkat, yang tercermin dari melajunya PDB, selayaknya dinikmati oleh rakyat banyak tersebut.

Harapan yang demikian itu jelas masih belum mewujud dalam ekonomi nasional. Dalam paparan data makro memang tak bisa dipungkirl banyaknya prestasi pembangunan ekonomi bangsa sampai tumbangnya rezim Orde Baru. Transformasi structural telah terjadi, sehingga wajah ekonomi kita dilihat dari kontribusi sumbangan sektoralnya semakin berimbang, dan "berwaiah industri" ataupun "berwajah modern". Sumbangan sektor industri dalam produksi nasional, yang pada awal Orde Baru masih kurang dari 10 persen kini sudah menguasai hampir seperempat dari produk nasional. Sebelum petaka ekonomi muncul di tahun 1997, ini dianggap sebagai tanda-tanda atau indikator yang mengarahkan kecenderungan ekonomi makro ke arah negara industri sesuai dengan sasaran pembangunan yang ada.

\section{Ketimpangan Ekonomi}

Namun jika kita kembali ke definisi di atas, untuk melihat lebih dalam tentang sejauhmana keterlibatan rakyat banyak dalam mendukung dan menikmati hasil kemajuan itu, maka sosok gambaran yang belum menggembirakanlah yang muncul. Dilihat dari pelaku atau jumlah pekerja di industri itu sendiri, misalnya, jumlahnya relatif masih sedikit. Sektor industri hanya menyerap $13 \%$ (1994) dari seluruh angkatan kerja yang ada. Sementara sektor pertanian, yang kontribusinya atas PDB terus merosot dan tinggal sekitar 17 persen, dan setiap tahun secara absolut sektor penyerap terbesar angkatan kerja baru yang ada, harus menampung $45 \%$ dari total angkatan kerja nasional. Semakin banyaknya pekerja di sektor modern yang di PHK, diperkirakan akan semakin membengkakkan jumlah pekerja di pertanian, sehingga akan memperbesar pula angka pengangguran tak kentara (disguissed unemployment) di sektor ini.

Dengan data di atas menggambarkan adanya ketimpangan pendapatan antar sektor yang ada. Sektor pertanian, yang dapat dikatakan sektor ekonomi rakyat, menikmati bagian kecil saja dari produk nasional. Sementara sektor industri, yang menyerap sedikit tenaga kerja menikmati bagian terbesar dari pendapatan nasional. Ketimpangan juga bisa dilihat dari sektor formal (yang merupakan bagian kecil dari perekonomian kita) dengan sektor informal (yang mewakili "ekonomi rakyat").

Dilihat secara lebih mikro dalam sektor industri sendiri, dengan melihat skala usahanya, maka akan menampakkan sosok ketimpangan yang lebih tajam lagi. Skala industri besar dan menengah, yang melibatkan 32,7\% (1990) dari total tenaga kerja industri, memperoleh output sebanyak $82,2 \%$ dari total output industri. Sementara, 
industri rakyat (industri kecil dan rumah tangga), yang menyerap $71,3 \%$ angkatan kerja industri, hanya menghasilkan 17,7 $\%$ dari total output industri. Jadi, sektor industri rakyat hanya menyumbang (dan juga menikmati) sedikit saja dari perkembangan industri nasional yang pesat ini.

Persoalan ekonomi rakyat ini ditambah pula dengan tingginya angka "setengah menganggur" (under employment) pada sektor pertanian ataupun industri rakyat tersebut. Memang jika dilihat angka tingkat "pengangguran terbuka" angkanya relatif rendah, yakni hanya 1, 99 juta atau $2,6 \%$ dari angkatan kerj a. Namun jika dimasukkan pula yang setengah menganggur, maka jumlahnya mencapai 28,95 juta atau $38 \%$ (1991) dari total angkatan kerja kita. Dapat diduga bahwa yang setengah menganggur ini kebanyakan terjadi pada sektor ekonomi rakyat banyak tersebut. Angka terakhir tentang pengangguran dan setengah menganggur ini jelas semakin besar saat ini, sebagai akibat menurunnya perekonomian sehingga menurunkan pula semua aktivitas produksi. Data dari Menaker menunjukkan, angka pengangguran penuh saat ini mencapai 15,4 juta orang atau $17,1 \%$ dari angkatan kerja yang jumlahnya 90 juta orang; sedangkan Bank Dunia mempredikasi lebih besar lagi, yakni 20 juta orang atau $21 \%$ dari total angkatan kerja (Kompas, 11/7/1998).

Dengan kondisi yang demikian maka tidak mengherankan kalau angka-angka yang mengindikasikan ketimpangan itu menjadi cukup tinggi. Bagian pendapatan yang diterima rakyat lapisan bawah semakin sedikit. Jika tahun 1971 , misalnya, $40 \%$ lapisan bawah masyarakat masih menikmati $26,76 \%$ dari pendapatan nasional, maka tahun 1990 porsi ini tinggal $14,61 \%$ saja, yang berarti kian kecilnya porsi pendapatan yang diterima lapisan bawah dari masyarakat Indonesia tersebut.
Namun demikian data makro itu sama sekali tidak bisa diartikan bahwa masyarakat miskin bertambah miskin. Memang ada yang tercecer dari pembangunan yang pesat ini, namun secara umum yang terjadi adalah yang miskin telah semakin "kaya", namun peningkatan "kekayaannya" jauh lebih lambat dibandingkan sebagian kecil rakyat yang berada dalam strata atas ekonomi kita. Petani, misalnya, produksinya secara absolut terus naik. Daya belinya juga meningkat. Namun peningkatan produksi dan daya bell itu lebih rendah dibandingkan pekerja di sektor lainnya.

Melihat gambaran di atas, maka wajar kalau kemudian muncul istilah "ekonomi kerakyatan". Istilah yang mungkin dari segi bahasa kurang tepat tersebut, muncul dengan maksud memberikan tekanan agar pembangunan masa datang lebih berorientasi untuk peningkatan yang lebih pesat bagi sektor-sektor ekonomi yang digeluti rakyat banyak. Artinya, rakyat banyak terlibat dalam proses produksinya dan sekaligus juga ikut menikmati hasil produksi tersebut secara layak.

Jika kita menginginkan pengembangan ekonomi yang mengakar dan berpihak pada kerakyatan, maka harus pula dilihat dalam konteks pembangunan yang dapat lebih "memberdayakan" rakyat banyak, melalui keterlibatanya dalam aktivitas ekonomiyakni aktivitas produksi, distribusi dan konsumsi-yang berarti pula memperkecil ketimpangan yang ada sekarang ini. Harus diakui bahwa sudah ada dan cukup banyak kebijakan yang diarahkan untuk memperkuat ekonomi rakyat. Namun demikian kebijakan tersebut masih kalah banyak dibanding yang dinikmati segelintir pelaku ekonomi lainnya. Karena itu diperlukan suatu pendalaman [deepening] dari kebijakan dan aksi yang lebih berorientasi pada ekonomi rakyat. 


\section{Ekonomi Rakyat di tengah Krisis}

Bagaimana penilaian tentang dampak krisis ekonomi rakyat saat ini, belum sepenuhnya semua pengamat ekonomi sependapat. Dalam seminar baru-baru ini, seorang ekonom menyatakan bahwa dalam krisis ekonomi yang terjadi sekarang ini, yang paling terkena akibatnya bukanlah ekonomi rakyat kecil, melainkan para pelaku ekonomi skala besar dan menengah yang secara langsung dikatakan mengalami kemerosotan drastis atau kehancuran. Sambil menceritakan perjalananya ke beberapa daerah, dikatakan bahwa masyarakat petani tanaman keras yang dilihatnya ternyata justru mengalami kebangkitan dengan adanya krisis moneter sekarang ini, sebagai akibat membaiknya harga jual produk pertanianya. Pandangan demikian, yang menganggap imbas krisis moneter hanya pada pelaku ekonomi kuat, diyakini sebagian pengamat ekonomi. Beberapa laporan surat kabar juga menunjukkan adanya sebagian anggota masyarakat yang justru "kaya mendadak" setelah adanya krisis moneter sekarang, seperti kasus beberapa petani tanaman keras, seperti petani kakao atau cengkeh, ataupun penambak udang.

Pandangan yang menyatakan bahwa hanya pelaku ekonomi kuat atau unit usaha di sektor modern yang menderita akibat krismon ini, kiranya perlu dipertanyakan. Pendapat demikian mungkin benar pada saat-saat awal krismon terjadi. Sektor modern umumnya terkait langsung dengan nilai tukar rupiah, utang luar negeri, dan terkait pula dengan sektor perbankan untuk pendanaan usahanya. Memburuknya variabel-variabel makro ekonomi itu, secara langsung dirasakan dampaknya oleh sektor modern tersebut. Oleh karena itu,tidak mengherankan kalau yang pertama-tama menjerit dari adanya krismon yang mulai merambah sejak pertengahan juli tahun lalu adalah sektor modern atau unit-unit usaha besar tersebut.

Namun demikian, tidak bisa dipungkiri, betapapun kecilnya, sektor usaha modern ini tidak berdiri sendiri, melainkan mengait dengan ekonomi rakyat banyak, baik dilihat dari sisi supply maupun demand. Oleh karena itu, kita tidak bisa "membutakan" diri untuk tidak melihat dampak ini. Inflasi yang tinggi telah membuat semua harga kebutuhan pokok meningkat. Demikian pula dengan harga bahan baku untuk industri kecil, dan sarana pendukung pertanian, semuanya mengalami peningkatan. Akibat dari semua ini, terefieksikan dari puluhan juta rakyat yang kesulitan untuk memperoleh sembako.

Memang benar ada petani-petani perkebunan atau petambak udang yang meraup untung besar karena produknya yang diekspor, sehingga dilihat dari sisi rupiah mereka bisa memperoleh pendapatan yang sangat tinggi, bahkan tidak terbayangkan sebelumnya. Namun demikian, dalam struktur pertanian kita, petani yang demikian porsinya hanyalah bagian terkecil dari pekerja di sektor pertanian kita. Yang terbanyak justru petani-petani tanaman pangan, yang meliputi bagian besar dari angkatan kerja di pertanian. Mereka ini sekarang berhadapan dengan harga kebutuhan pokok yang semakin mahal, yang tidak bisa dijkuti oleh kenaikan pendapatannya. Sebagian besar petani beras, misalnya, terpaksa menjual beras di saat musim panen dengan harga relatif murah, karena desakan kebutuhan sehari-hari dan membayar utangnya. Namun mereka menjadi konsumen di saat paceklik, di mana harus membeli beras di pasar dengan harga tinggi. Dampak yang sama juga mengena pada pedagang kecil, pengrajin.kecil, atau buruh-buruh industri dan bangunan yang terpaksa berhenti bekerja karena menu- 
runnya aktivitas di sektor manufaktur dan konstruksi. Jadi, adalah sangat naif kalau dikatakan bahwa dampak krismon lebih dirasakan oleh unit usaha besar, dan tidak menyentuh ekonomi rakyat.

Dalam kondisi sekarang, mayoritas masyarakat Indonesia terkena dampak krisis moneter yang sudah menjadi krisis ekonomi secara menyeluruh. Hanya saja tingkatan dampak tersebut bagi kehidupan individual adalah berbeda-beda, namun tetap saja secara absolut rakyat kebanyakan dari kelas menengah ke bawah yang paling menderita, dan bukan sebaliknya. Bagi masyarakat yang kaya, mereka masih mempunyai waktu bertahan yang lama dari krisis moneter ini tanpa terganggu kelangsungan hidupnya secara berarti. Walaupun unit usahanya merosot, atau pendapatan/ gaji yang diterima menurun, pada tahapan awal mereka masih bisa mempertahankan tingkat sosial-ekonominya dengan menggunakan tabungan yang dimiliki.Oleh karena itu, tidak mengherankan kalau di tengah krisis sekarang ini masih banyak penduduk kelas menengah atas bisa mengisi liburannya di obyek-obyek rekreasi luar kota, atau bahkan ke luar negeri. Seandainya dana simpanan tersebut sudah habis, mereka masih bisa menekan konsumsinya atas barang-barang sekunder dan tersier, atau menggeser pola pengeluarannya, tanpa terganggu kebutuhan pokok (basic needs)-nya. Kalau tadinya mereka menyekolahkan anaknya di Amerika, misalnya, saat ini "ditarik" untuk pindah ke Australia atau ke negara-negara Asia lainnya, yang relatif lebih murah.

Keadaan sangat berbeda dengan rakyat kebanyakan, yang seluruh pendapatannya sudah habis dibelanjakan. Dalam suasana krisis yang bekepanjangan ini, tidak ada pilihan lain bagi yang masuk dalam kelompok ini kecuali mengurangi konsumsinya yang sudah sangat terbatas tersebut, dan pada saatnya mereka pun bisa kehabisan daya beli sama sekali. Mereka inilah yang daya belinya sekarang sangat merosot dan terancam rawan pangan. Jumlah penduduk yang rawan pangan ini sudah mencapai 40 juta orang, dan bisa terus bertambah jika ekonomi kita makin memburuk. Adanya aksi-aksi penjarahan dan kenekadan yang dilakukan para pelaku tindak kriminal, sebagian merefleksikan karena kesulitan untuk memenuhl kebutuhan pokok tersebut. Misalnya saja, kasus penjarahan tambak udang di daerah Tangerang (Teluk Naga) - Jawa Barat yang dilakukan penduduk sekitar tambak atas tambak udang yang belum dipanen, menunjukkan betapa sudah nekadnya para penjarah tersebut. Perkebunan kopi di Banyuwangi dijarah oleh ribuan penduduk. Juga penjarahan minyak goreng terjadi di Pasar Murah yang baru diresmikan oleh. Presiden BJ Habibibe di Jakarta (18/7/1988). Para penjarah ini tentu bukan manusia-manusia yang tidak mengerti dosa atau tidak mempunyai norma-norma atau aturan dalam hidupnya. Saya yakin ada di antara penjarah itu orang yang khusyu melaksanakan ibadahnya. Akan tetapi, dengan penghayatan yang terbatas, karena tuntutan kebutuhan pokok yang mendesak, mereka tega menjarah tambak udang yang ada di lingkungannya, atau menjarah milik pengusaha yang sebetulnya saat ini samasama dalam kesulitan ekonomi. Kasus seperti ini sangat mungkin meluas dalam berbagai bentuknya apabila krisis ekonomi terus berlanjut, sebagai akibat tuntutan kebutuhan pokok yang harus dipenuhi dan tidak bisa ditunda.

\section{Catatan Agenda Aksi}

Dengan terminologi yang sejalan dengan tulisan ini, dapat dikatakan bahwa ekonomi rakyat yang paling besar terkena 
dampak krisis ini. Adanya ekses ekonomi seperti dilukiskan diatas, dan tidak mampunya ekonomi rakyat berperan mengatasi krisis ini, dikarenakan ada beberapa sebab, yang dapat dirumuskan sebagai berikut, pertama selama pemerintahan Orde Baru, kegiatan ekonomi yang dilakukan rakyat kebanyakan tidak mempunyai kesempatan untuk berkembang. Kedua, adanya pemihakan pemerintah Orde Baru kepada pemodal besar dan para pengusaha kakap yang memanfaatkan utang luar negeri yang kini memperbesar krisis ekonomi, serta pendangkalan keterkaitan industri dalam negeri. Oleh karena itu, langkah ke depan terutama adalah meluruskan kebijakan yang keliru ini, yakni memberikan peluang bagi unit usaha ekonomi rakyat untuk berkembang, dan secara nyata menunjukkan keberpihakan kepada ekonomi rakyat.

Dengan mendifinisikan mengenai konsep-konsep ekonomi rakyat dan beberapa ilustrasi yang menggambarkan ekonomi makro selama ini, pertanyaan yang muncul adalah apa yang harus dilakukan untuk mengembangkan ekonomi rakyat ini? Secara cukup sistematis Mubyarto [1997, h.37] mengemukakan tiga langkah yang perlu dilakukan, yaitu pertama, menciptakan suasana atau iklim yang memungkinkan masyarakat untuk berkembang. Dasar pemikiranya adalah bahwa setiap individu dan masyarakat mempunyai suatu potensi yang dapat dikembangkan, dan tidak ada masyarakat yang sama sekali tanpa daya. Kedua, memperkuat potensi ekonomi yang dimiliki masyarakat tersebut. Untuk itu langkah pokok yang harus dilakukan adalah peningkatan taraf pendidikan, kesehatan, dan terbukanya kesempatan untuk memanfaatkan peluang ekonomi. Ketiga, melindungi ekonomi rakyat dan mencegah terjadinya persaingan yang tidak seimbang, serta mencegah eksploitasi golongan ekonomi yang kuat atas yang lemah.
Tiga langkah di atas agaknya merupakan prakondisi yang harus diciptakan terlebih dulu untuk dapat mewujudkan suatu tatanan ekonomi yang dalam aktivitasnya melibatkan rakyat banyak. Adalah tidak mungkin ekonomi rakyat berkembang efisien, kalaụ ada pembedaan perlakukan pada para pelaku ekonomi kecil-besar. Misalnya saja dalam upaya permodalan, selama ini diketahui bahwa unit usaha besar lebih mudah dan murah memperoleh kredit, ketimbang unit-unit usaha ekonomi rakyat yang terkadang harus memperoleh modal dari kreditor informal dengan tingkat bunga yang mahal. Sejauh ini alokasi kredit yang diberikan kepada bank-bank terbanyak masuk ke sektor modem, yang secara relatif hanya sebagian kecil masyarakat menggelutinya. Wajah dari distribusi perkreditan yang dilakukan perbankan di tanah air yang memang hanya berhasil dinikmati oleh sebagian kecil rakyat. Perkembangan tersebut menunjukkan bahwa sektor ekonomi rakyat banyak, seperti pertanian, perdagangan dan industri kecil, hanya menikmati sebagian kecil dari porsi kredit yang ada. Sektor industri, perdagangan dan jasa-jasa berskala besar, walaupun hanya menampung relatif se Jikit tenaga kerja, merupakan penyerap terbanyak dari kredit perbankan nasional.

Adanya kecenderungan perekonomian yang kian terbuka akan sangat mungkin kian mempersulit ekonomi kerakyatan ini. Dalam ekonomi terbuka dan persaingan bebas yang ketat, maka hanya mereka yang mempunyai akses terhadap faktor produksi yang berpeluang bertahan atau menang. Padahal ekonomi-ekonomi yang gurem adalah sangat jauh dari akses memperoleh modal, kredit, informasi, tekhnologi, peningkatan skill, terlebih lobby bisnis. Akibatnya, mereka bisa tercecer di belakang dari perkembangan ekonomi yang bebas. Memang sebagian ekonomi rakyat di tanah 
air relatif sudah terbiasa dengan persaingan yang agak bebas tanpa perlindungan tersebut, namun demikian tanpa adanya upaya untuk membantu akan menyebabkan mereka tetap bertahan pada posisi "status quo' yang ada.

Oleh karena itu, pengembangan ekonomi kerakyatan berarti harus ada reorientasi strategi pembangunan yang memihak kepada rakyat banyak, atau yang memberi peluang kepada sebagian besar rakyat untuk terlibat dalam proses pembangunan ekonomi itu, dan menikmati hasil dari keterlibatanya secara layak. Dengan kata lain dibutuhkan suatu pemberdayaan ekonomi rakyat agar mereka-paling tidak dalam tahap transisi dewasa ini-dapat mempunyai akses-akses yang bisa memperbesar kemampuanya dalam perekonomian. Dengan demikian, kebijakan yang ada memang harus bias ke ekonomi rakyat dalam rangka memperkuat posisinya untuk bersaing di pasar yang kian terbuka tersebut. Dikaitkan dengan harapan-harapan untuk mewujudkan masyarakat Indonesia Baru, maka tuntutan perubahan strategi dan perubahan action ini menjadi relevan, terutama dalam rangka meluruskan berbagai strategi dan kebijakan yang selama masa orde Baru dirasakan jauh dari keberpihakan pada rakyat banyak.

Dewasa ini sebagian besar angkatan kerja dan rakyat kita hidup dari pertanian. Walaupun sektor ini terus berkembang, namun secara absolut penduduk yang tergantung pada sektor ini juga kian bertambah. Sebagian tenaga kerja di pertanian tersebut juga tidak bekerja penuh (under empployment), karena relatif terbatasnya lahan sementara tenaga kerja terus bertambah. Akibatnya pendapatan rïl penduduk di sektor pertanian menjadi relatif lamban pertumbuhannya. Hal ini terjadi karena peluang kerja di luar sektor pertanian belum mampu menyediakan peluang kerja dan berusaha agar dapat menarik sebagian tenaga kerja yang ada di pertanian, atau menyerap setiap pertambahan angkatan kerja yang ada.

Merupakan "pekerjaan rumah" yang tidak gampang bagi penyusun kebijakan dalam memecahkan masalah tersebut di atas. Sektor industri memang sangat diharapkan dapat menyerap lebih banyak tenaga kerja yang ada tersebut. Namun dengan struktur industri yang ada sekarang, yang keterkaitannya sangat rendah ántara industri besar dan kecil, maka susah diharapkan hal itu terjadi. Idealnya, industri-industri besar dalam proses produksinya mengaitkan dengan industri yang lebih kecil untuk memasok inpurnya. Ini juga akan memperkuat struktur industri kita. Dalam struktur industri yang kuat, maka keterkaitan industri besar dengan industri menengah-kecil ini sangat dibutuhkan. Keterkaitan yang tinggi akan sangat mendukung daya tahan ekonomi nasional terhadap goncanganjekonomi internal maupun ekstemal (Riżal Ramli, $f$ 995). Pola ini agaknya sangat mendukung pengembangan ekonomi rakyat, karena adanya beberapa dampak dari pola tersebut. Dampak tersebut antara lain adalah: (a) dengan tingginya keterkaitan, maka ekspansi usaha bisnis yang dilakukan perusahaan besar akan diikuti pula oleh ekspansi bisnis skala menengah-kecil, yang akan berdampak pada peningkatan pendapatan dan lapangan kerja; (b) mengurangi kesenjangan ekonomis antar-unit usaha yang ada; (c) akan mendorong produktivitas dalam negeri yang tinggi, yang pada akhirnya akan menciptakan competitive advantage yang tinggi (lihat Rizal Ramli, 1995).

Untuk mewujudkan hal tersebut berarti harus diciptakan suatu iklim yang membuat industri skala besar juga merasa membutuhkan kehadiran industri skala lebih kecil untuk mendukung proses produksinya. Jadi, tak sekedar karena belas-kasihan yang 
menyebabkan terjadinya hubungan antarindustri tersebut. Bagaimana pola dan penciptaan iklim tersebut inilah yang tampaknya masih perlu terus didiskusikan lebih lanjut.

\section{Daftar Pustaka}

Anggito Abimanyu, "Orientasi Usaha dan Kinerja Bisnis Konglomerat', pada jurnal UNISIA, No. 25/1995

Edy Suandi Hamid, "Ekonomi Kerakyatan di Tengah Kecenderungan Keterbukaan Ekonom ${ }^{2}$, makalah pada diskusi panel Ekonomi Kerakyatan Harian Pikiran Rakyat, Yogyakarta, 1995

Edy Suandi Hamid, "Lahimya Dikotomi Ekonomi Rakyat dan Non-Rakyaf', Bisnis Indonesia, Jakarta, 2 September 1995

Edy Suandi Hamid, "Perilaku Industri dan
Konglomerasi di Indonesia ", pada jurnal UNISIA, No. 25/1995

Fakultas Ekonomi Univesitas Indonesia, Laporan Konferensi tentang Krisis Ekonomi Indonesia, FE Ul, Jakarta, 1999

Iqbal, Farrukh, "Deregulation and Development in Indonesia", makalah pada seminar Building on Success: Maximizing the Gains from deregulation, Jakarta, 1995

Mubyarto, Ekonomi Rakyat, Program IDT dan Demokrasi Ekonomi Indonesia, Aditya Media, Yogyakarta, 1997

Rizal Ramli, "Inefisiensi Ekonomi Indonesia: Kerangka Konseptual dan Perubahan Struktur Industri:, makalah pada Sidang Pleno ISEI ke-8, Manado, 1995

Sarbini Sumawinata, Revolusi 1998, Yayasan Kerakyatan, Jakarta, 1998 